\title{
EFEKTIVITAS RUANG TERBUKA PUBLIK SEBAGAI TITIK KUMPUL BENCANA DI KELURAHAN MACCINI SOMBALA, SULAWESI SELATAN
}

\author{
Nuryuningsih $^{1 *}$, Mayyadah Syuaib ${ }^{1}$, Rahmadi Rahim ${ }^{2}$ \\ ${ }^{1}$ Jurusan Teknik Arsitektur \\ Fakultas Sains dan Teknologi UIN Alauddin Makassar \\ Jl. Sultan Alauddin No. 63, Kabupaten Gowa, Sulawesi Selatan. 92113 \\ ${ }^{2}$ Four Arc Design \\ Jl. Komp. Pemda, Kota Makassar, Sulawesi Selatan. 90222 \\ *E-mail: uni.nuryuningsih@ uin-alauddin.ac.id
}

\begin{abstract}
Abstrak: Penelitian ini bertujuan untuk menganalisis tingkat efektivitas ruang terbuka dengan mengidentifikasi faktor-faktor yang memengaruhi dan merumuskan strategi untuk meningkatkan partisipasi masyarakat dalam pengembangan ruang terbuka sebagai titik temu bencana di Desa Maccini Sombala Makassar, dengan melakukan studi literatur, observasi dan wawancara. Berdasarkan Teori Arnstein sebagai instrumen dan analisis datanya menggunakan teknik analisis korelasi antar variabel untuk mengetahui relevansinya dengan tingkat partisipasi masyarakat. Hasil penelitian menunjukkan bahwa ruang terbuka publik kurang efektif dilihat dari tingkat partisipasi masyarakat sesuai dengan jenjang pertama Teori Arnstein (manipulasi), sebanyak 45 responden atau $75 \%$ data. Faktor-faktor yang memengaruhi antara lain: umur dan jarak ruang terbuka publik dari rumah. Berdasarkan hal tersebut, strategi peningkatan partisipasi masyarakat dalam pengembangan ruang terbuka sebagai titik temu bencana di Desa Maccini Sombala meliputi: pemberian penyuluhan, kerjasama pemerintah, pemberian pelatihan tanggap bencana, bahkan pemberian kesempatan kepada masyarakat untuk berpartisipasi penuh di beberapa ruang terbuka publik. program pembangunan seperti penentuan titik temu bencana yang telah disepakati melalui konsultasi, diskusi, dan lain-lain sesuai dengan harapan masyarakat pada umumnya.
\end{abstract}

Kata Kunci: bencana, meeting point, ruang terbuka, partisipasi masyarakat

\section{PENDAHULUAN}

$\mathrm{R}$ uang terbuka publik merupakan salah satu kebutuhan masyarakat khususnya di wilayah perkotaan sebagai sarana penunjang untuk melakukan berbagai aktivitas. Melihat fungsi ruang terbuka bagi masyarakat setempat, menurut Carr et al. (1992) dalam Sakti (2009), ruang terbuka publik berfungsi sebagai simpul dan sarana komunikatif serta sebagai pengikat sosial untuk menciptakan interaksi antara kelompok masyarakat juga sebagai tempat berkumpul sehari-hari dan pada kesempatan khusus.

Kota Makassar memiliki beberapa ruang terbuka publik yang berada di kawasan permukiman, ruang terbuka ini tergolong ruang terbuka aktif, yaitu ruang terbuka yang memiliki unsur-unsur kegiatan di dalamnya, contoh: plaza, tempat bermain anak, penghijauan tepi sungai sebagai tempat rekreasi, lapangan olah raga, dan lain sebagainya. Keberadaan ruang terbuka publik yang masih belum disadari pentingnya bagi masyarakat 
saat ini berdampak pada potensi lain yang juga masih belum disadari adalah ruang terbuka publik sebagai bagian dalam penanggulangan bencana, dengan kata lain ruang terbuka publik dapat dijadikan sebagai titik kumpul atau tempat evakuasi saat terjadi bencana sehingga meminimalkan jatuhnya korban. Oleh sebab itu akses menuju ruang terbuka publik juga penting untuk diperhatikan agar masyarakat dapat mencapai lokasi evakuasi yang aman.

Bencana yang terjadi tidak dapat diprediksi, apapun itu akan terjadi secara tiba-tiba, oleh sebab itu perlu diperhatikan fasilitas-fasilitas dan tindakan-tindakan yang dapat mengedukasi masyarakat terhadap tanggap bencana tersebut. Di Indonesia dalam beberapa tahun ini telah banyak terjadi bencana-bencana di berbagai daerah termasuk di Kota Makassar. Terlebih lagi pada kawasan pemukiman yang padat seperti di Kelurahan Maccini Sombala Kecamatan Tamalate yang pada tahun 2017 mengalami bencana banjir dengan korban 40 rumah dan 60 KK (Hasil Wawancara dengan Lurah Maccini Sombala) dan kebakaran beberapa rumah warga di tahun 2018 dan 2019 (inews.id). Dilihat dari data beberapa tahun terakhir, di Kelurahan Maccini Somabala hampir setiap tahun mengalami bencana, ditambah lagi padatnya permukiman warga, maka perlu diperhatikan lokasi atau tempat-tempat dan tindakan yang dapat mengedukasi warga akan tanggap bencana.

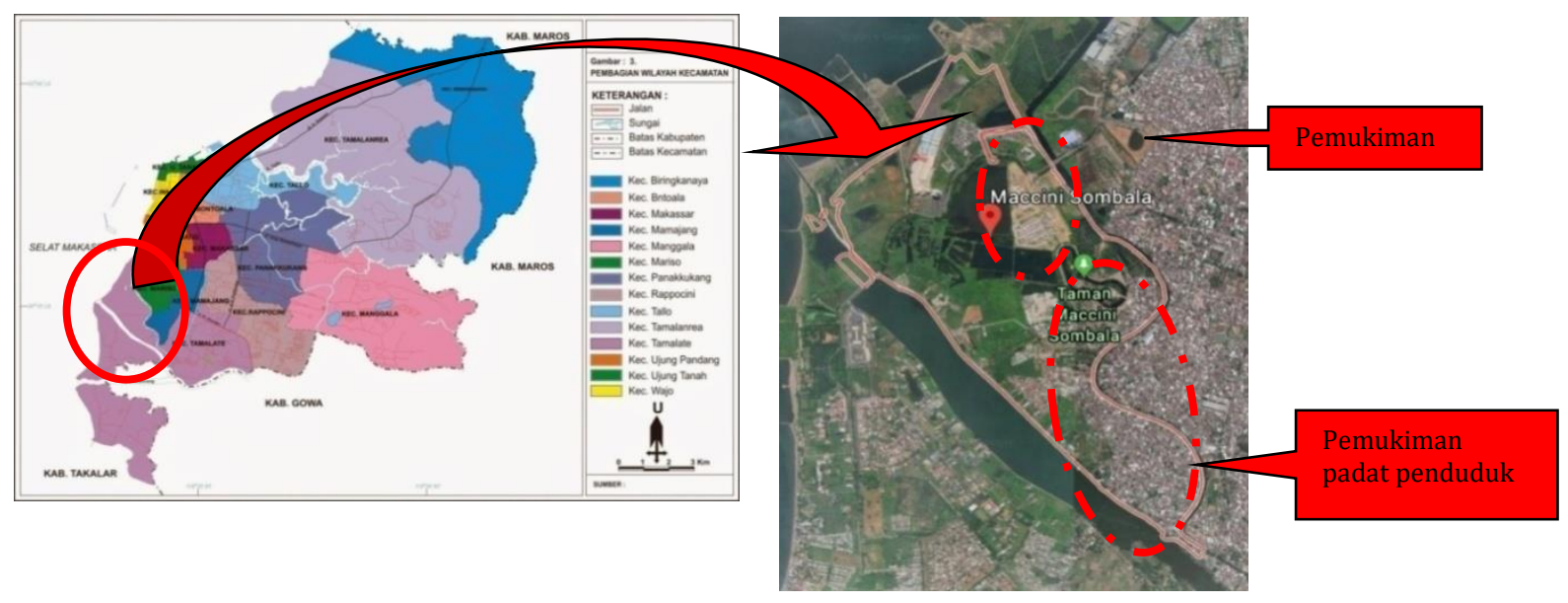

Gambar 1: Peta Kelurahan Maccini Sombala, Kecamatan Tamalate, Makassar (BKPSDMD Kota Makassar, 2020)

Penanggulangan bencana utamanya di lingkungan perumahan atau kawasan penduduk perlu difasilitasi, salah satunya adalah tempat evakuasi bencana atau titik kumpul. Tempat ini merupakan ruang terbuka yang berada di dekat kawasan penduduk, dapat berupa plaza, lapangan olahraga atau taman. Titik kumpul bencana sebaiknya dapat melayani masyarakat dengan cepat dan efisien berfungsi sebagai tempat berkumpul penduduk setempat, dapat dimanfaatkan sebagai tempat mengungsi sementara, dimana pendataan dapat dilakukan dan mempermudah penyaluran bantuan.

Titik kumpul bencana pada suatu kawasan biasanya ditentukan oleh instansi pemerintah yaitu Badan Penanggulangan Bencana Daerah (BPBD) dengan mempertimbangkan beberapa parameter yang memengaruhi tingkat keefektifan titik kumpul tersebut. Namun begitu karena penentuan ditentukan oleh pemerintah, masyarakat kurang mengetahui tempat evakuasi. Agar tempat tersebut dapat dengan mudah dipahami oleh masyarakat sekitar wilayah Kelurahan Maccini Sombala, maka dapat diberi informasi dan diterapkan pembuatan penanda tempat evakuasi atau titik 
kumpul secara partisipatif dengan mempertimbangkan pendapat warga sebagai parameter utama.

Titik kumpul sebaiknya dapat memfasilitasi masyarakat dalam satu wilayah kelurahan Maccini Sombala sehingga dapat mengurangi tingkat kerugian dan korban bencana. Dimana infrastruktur ini dapat menguatkan kesiapsiagaan dan mengurangi kerentanan masyarakat dalam menghadapi bencana. Titik kumpul sebagai tempat berkumpul sementara selama situasi tanggap bencana sebaiknya dapat memfasilitasi masyarakat yang berada di pemukiman tersebut. Titik kumpul memerlukan partisipasi masyarakat dalam proses penentuannya. Peran pemerintah diperlukan untuk memberikan arahan dalam proses penentuan dan tindakan-tindakan informasi yang dapat mengedukasi.

Peran serta masyarakat dalam penentuan dan pemberian informasi mengenai titik kumpul dengan tujuan ruang terbuka publik dapat digunakan dengan maksimal. Profil masyarakat yang tergolong menengah ke bawah dengan kodisi permukiman padat penduduk cenderung hanya menerima hasil perencanaan dari pemerintah kecuali bila adanya program pemberdayaan masyarakat. Penentuan maupun informasi mengenai titik kumpul dikaji secara partisipatif sehingga dapat memahami kebutuhan masyarakat terhadap tempat evakuasi untuk kepentingan mitigasi bencana. Kondisi titik kumpul yang tidak mendukung dapat menambah kerentanan masyarakat terhadap bahaya bencana dan partisipasi masyarakat yang masih minim dalam proses penentuan dan informasi titik kumpul menimbulkan ketergantungan yang berlebih dari masyarakat ke pemerintah. Oleh karena itu perlu diteliti mengenai efektivitas titik kumpul dari persepsi masyarakat dan informasi mengenai ruang terbuka publik yang dapat dijadikan sebagai titik kumpul dalam rangka menekan resiko bencana yang ada. Tujuan penelitian ini adalah: 1) Mengidentifikasi persepsi masyarakat terhadap pemanfaatan ruang terbuka publik sebagai titik kumpul bencana; 2) Menganalisis faktor-faktor yang memengaruhi partisipasi masyarakat dalam pengembangan ruang terbuka publik di Kelurahan Maccini Sombala; 3) Mengetahui strategi peningkatan partisipasi masyarakat terhadap ruang terbuka publik sebagai titik kumpul bencana.

Proses evakuasi saat bencana merupakan upaya pengungsian korban disebabkan situasi yang memaksa individu untuk berpindah dari tempat bencana. Evakuasi dapat terjadi akibat bencana fenomena alam, antara lain cuaca ekstrim (angin ribut, badai, dan kebakaran yang dikarenakan kondisi alam yang kekeringan), dapat juga akibat dari fenomena geologi seperti aktivitas gunung merapi, tsunami ataupun gempa bumi. Serta dapat pula diakibatkan oleh dampak dari aktivitas manusia antara lain: kegagalan teknologi, kecelakaan industri, serangan teroris dan kecelakaan. Tindakan evakuasi dilakukan dengan tujuan untuk menekan risiko dan konsekuensi yang ada meskipun kejadian bencana yang ada belum pasti mengenai wilayah tersebut (Zuilekom K et al., 2006 dalam Abraham W, 2015). Zonasi evakuasi dan ruang evakuasi (titik kumpul) menurut Permen PU No. 20 tahun 2011 memiliki ketentuan umum, yaitu sebagai berikut:

a. Pemanfaatan ruang yang diperbolehkan adalah sebatas ruang terbuka hijau;

b. Kegiatan yang diizinkan adalah pemasangan rambu, papan peringatan bencana, perhubungan, dan komunikasi;

c. Kegiatan yang tidak diizinkan adalah kegiatan yang dapat menghambat kelancaran akses jalur evakuasi. 


\section{METODE PENELITIAN}

Pada penulisan ini menggunakan pendekatan kualitatif-kuantitatif yaitu dengan memberikan fakta kualitatif tentang kondisi di lapangan. Memposisikan partisipan sebagai subjek, tidak membatasi jawaban dari setiap pertanyaan yang tersedia, tetapi memberikan lebih banyak kesempatan kepada partisipan untuk menyampaikan informasi yang dimiliki dan relevan dengan tujuan penelitian. Analisis yang dilakukan adalah mendeskripsikan fenomena yang terjadi di lapangan dengan mengambil Teori Arnstein sebagai instrumennya, menganalisis datanya menggunakan teknik analisis korelasi antar variabel untuk mengetahui keterkaitannya dengan tingkat partisipasi masyarakat. Pengukuran di lapangan dilakukan dengan wawancara dan observasi untuk mendapatkan informasi terkait fenomena yang diteliti. Variabel yang digunakan dalam penelitian diuji dengan analisis deskriptif untuk mendeskripsikan suatu fenomena secara detail

Penelitian dilakukan di Desa Maccini Sombala. Pemilihan lokasi didasarkan pada pengalaman terjadinya banjir dan kebakaran di permukiman padat penduduk. Hal tersebut dapat diredam dengan upaya mitigasi yang dilakukan oleh masyarakat dan pemerintah. Salah satu upaya mitigasinya adalah dengan menentukan titik temu agar masyarakat dapat mengantisipasi bencana secara dini. Kegiatan yang dilakukan di lapangan meliputi wawancara dengan masyarakat dan aparat desa serta observasi kondisi lapangan. Pengumpulan data primer dilakukan dengan cara mewawancarai masyarakat untuk mendapatkan data yang relevan dengan tujuan pertama. Pengamatan juga dilakukan untuk mendapatkan justifikasi data. Data sekunder dikumpulkan melalui pendataan yang dimiliki oleh instansi terkait. Penelitian ini menggunakan data sekunder yang dapat diperoleh dari pemerintah desa untuk data terkait bencana. Sedangkan data citra penginderaan jauh dapat diperoleh dari penyedia citra penginderaan jauh oinline seperti Google Map.

\section{HASIL DAN PEMBAHASAN}

\section{Deskripsi Distrik Maccini Sombala}

a. Masyarakat di Kelurahan Maccini Sombala

Desa Maccini Sombala, dengan jumlah penduduk $3.062 \mathrm{KK}$, memiliki penduduk heterogen dengan tingkat kepekaan yang tinggi. Hal ini sering ditandai dengan masih adanya gesekan antar tetangga, namun dalam batas-batas yang masih dapat dikendalikan.

b. Identifikasi Program RTH Taman Maccini Sombala oleh Pemerintah

Berdasarkan jenis proyek, Maccini of Indonesia adalah Development Waterfront. Taman seluas 14 hektar yang memiliki kanal sepanjang $1.224 \mathrm{~m}$ dengan lebar 34 meter. 


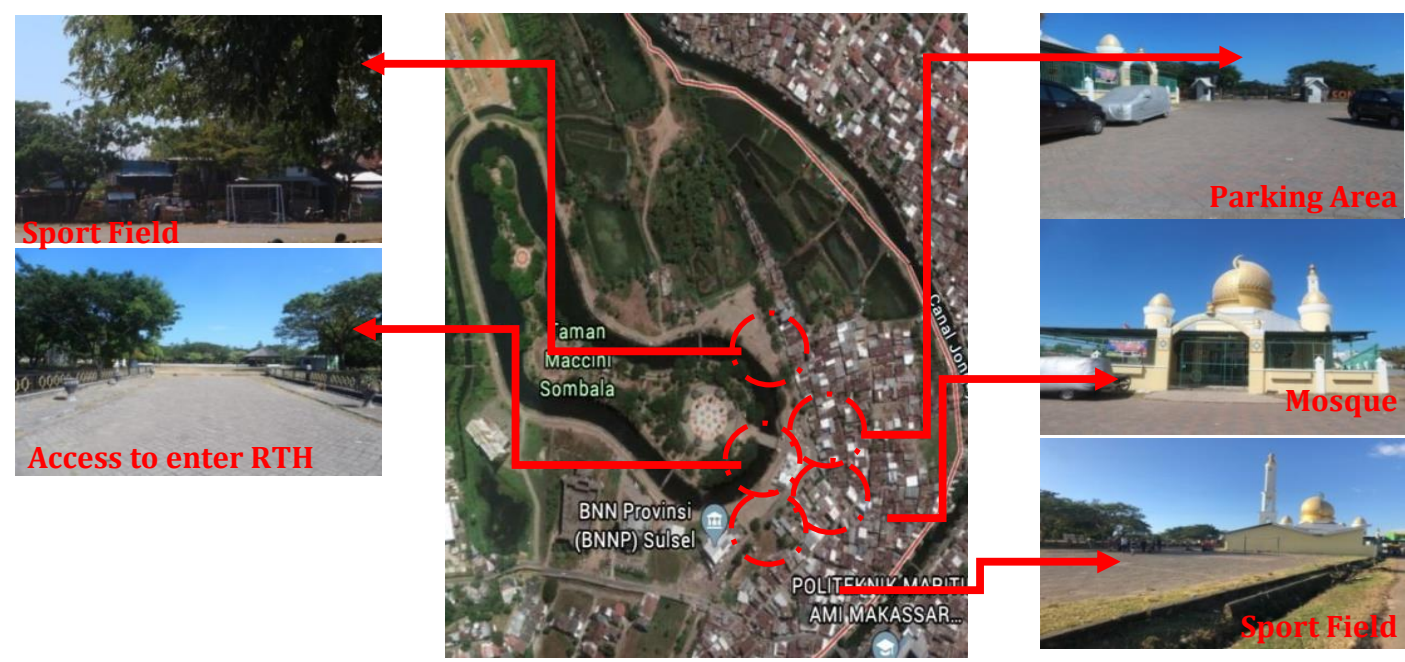

Gambar 2: Kondisi dan desain Taman Maccini Sombala

\section{Persepsi Masyarakat Terhadap Titik Kumpul Bencana}

a. Deskripsi Identitas Responden

Deskripsi karakteristik responden adalah untuk mendeskripsikan atau memberikan gambaran tentang identitas responden dalam penelitian ini. Identitas responden dalam penelitian ini dapat dikelompokkan menjadi beberapa kelompok yaitu: jenis kelamin, pekerjaan, pendidikan, jarak ruang terbuka dari rumah. Jumlahnya 60 responden, semua kuesioner dikembalikan dan semuanya bisa diproses lebih lanjut. Uraian terkait responden ditunjukkan pada Gambar 3.

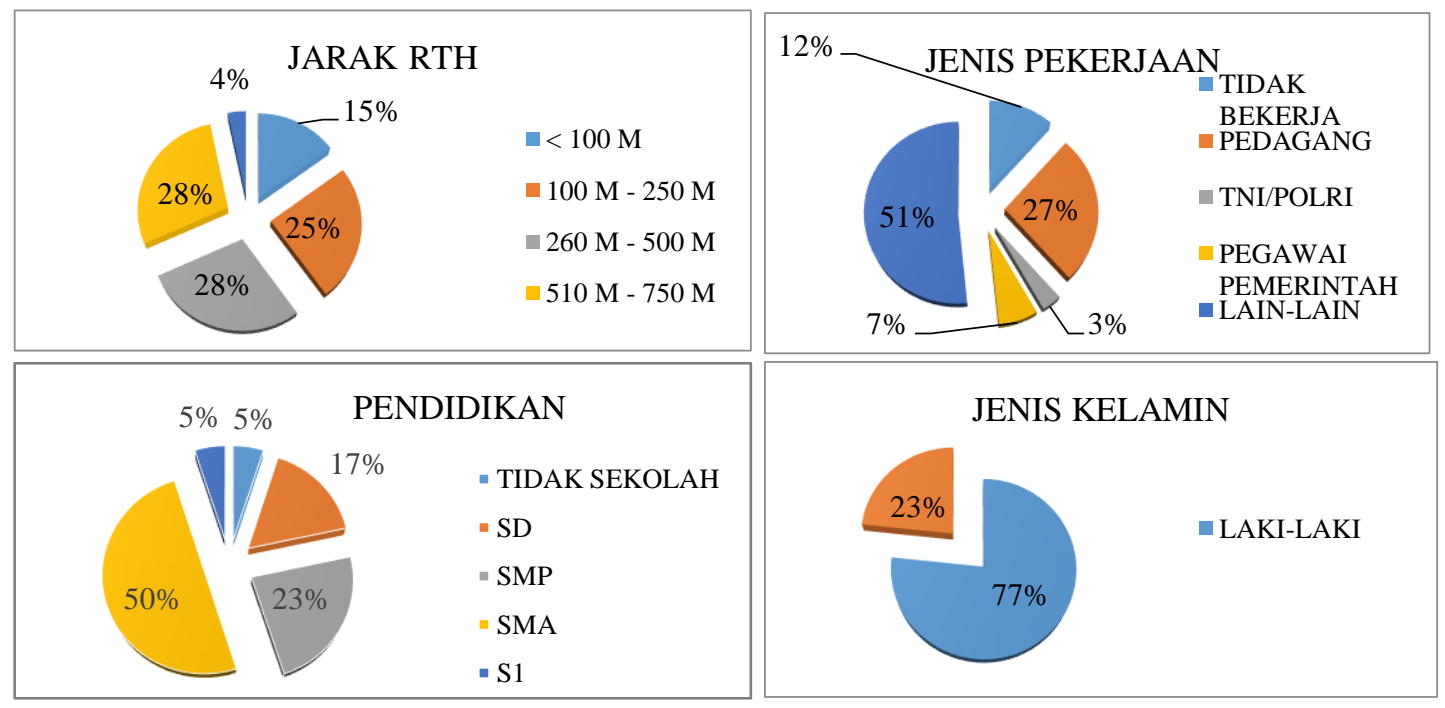

Gambar 3. Identitas responden

b. Persepsi publik terhadap ruang terbuka publik sebagai titik kumpul bencana Hasil penskoran data angket yang diperoleh di lapangan diperoleh data yang menunjukkan jumlah pendapat responden menurut Tangga Partisipasi Sheery Arnstein (Tabel 1). 
Tabel 1. Tingkat partisipasi masyarakat

\begin{tabular}{|l|l|l|c|c|}
\hline No & $\begin{array}{c}\text { Tangga/Tingkatan } \\
\text { Partisipasi }\end{array}$ & \multicolumn{1}{|c|}{ Penjabaran untuk Ruang Terbuka Publik } & $\begin{array}{c}\text { Masyarakat } \\
\text { Tanggap } \\
\text { Bencana }\end{array}$ & \% \\
\hline $\mathbf{8}$ & Community Control & $\begin{array}{l}\text { Pengembangan Ruang Terbuka Publik sepenuhnya } \\
\text { dilakukan oleh masyarakat, termasuk dalam } \\
\text { penanggulangan bencana }\end{array}$ & - & - \\
\hline $\mathbf{7}$ & Delegated Power & $\begin{array}{l}\text { Pengembangan ruang terbuka yang didanai oleh } \\
\text { pemerintah, tetapi pelaksanaan dan penentuannya } \\
\text { sebagai titik kumpul bencana diserahkan sepenuhnya } \\
\text { kepada masyarakat }\end{array}$ & - & - \\
\hline $\mathbf{6}$ & Partnership & $\begin{array}{l}\text { Pengembangan ruang terbuka publik dilakukan bersama } \\
\text { oleh pemerintah dan masyarakat, baik dalam penentuan, } \\
\text { perencanaan, maupun pelaksanaannya sebagai titik } \\
\text { kumpul bencana }\end{array}$ & - & - \\
\hline $\mathbf{5}$ & Consultation & $\begin{array}{l}\text { Pemerintah mengajak masyarakat berembuk atau } \\
\text { kesepakatan dalam penentuan uang terbuka publik } \\
\text { sebagai titik kumpul bencana di lingkungan perumahan }\end{array}$ & - & - \\
\hline $\mathbf{4}$ & Placation & $\begin{array}{l}\text { Pemerintah memberi penyuluhan dan memberi pelatihan } \\
\text { kepada masyarakat untuk tanggap bencana }\end{array}$ & 6 & 10 \\
\hline $\mathbf{3}$ & Informing & $\begin{array}{l}\text { Pemerintah mendengarkan saran masyarakat tentang } \\
\text { penentuan ruang terbuka publik sebagai titik kumpul } \\
\text { bencana tetapi tidak semuanya dipakai }\end{array}$ & 7 & 12 \\
\hline $\mathbf{2}$ & Therapy & $\begin{array}{l}\text { Masyarakat hanya diberi brosur atau petunjuk terhadap } \\
\text { ruang terbuka publik sebagai titik kumpul bencana }\end{array}$ & 2 & 3 \\
\hline
\end{tabular}

Secara deskriptif Tabel 1 menunjukkan frekuensi tertinggi berada pada level Tangga Arnstein pertama. Sebanyak 45 responden atau $75 \%$ sampel penelitian menyatakan hanya mendapat penjelasan tentang pentingnya ruang terbuka publik sebagai titik temu bencana yang dilakukan oleh pemerintah.

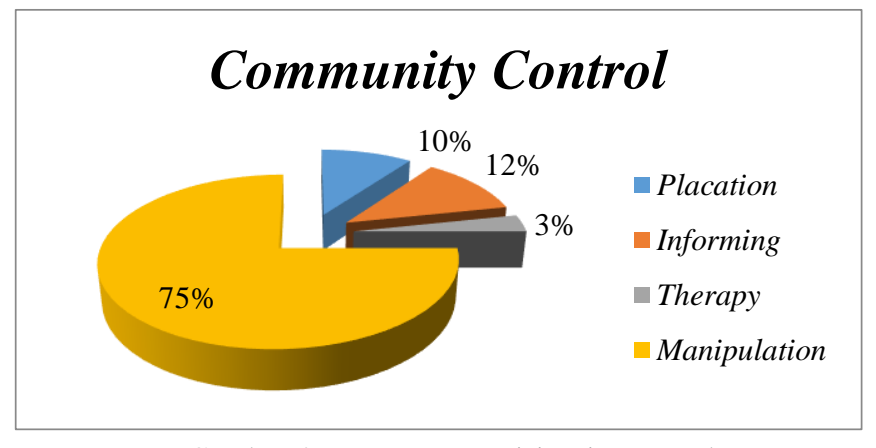

Gambar 4. Persentase partisipasi masyarakat

\section{Faktor-Faktor yang Memengaruhi Tingkat Partisipasi Masyarakat}

Untuk mengetahui faktor-faktor yang memengaruhi tingkat partisipasi masyarakat maka digunakan teknik analisis SPSS untuk mengorelasikan antar variabel guna mengetahui hubungan antar variabel dengan tingkat partisipasi. Beberapa variabel menjadi faktor yang signifikan dalam tingkat partisipasi masyarakat dan juga dapat dilihat sebagai hubungan antara masing-masing variabel yang saling memengaruhi. Pada tabel analisis korelasi (Tabel 2) terdapat 2 variabel yang memengaruhi yaitu pertama adalah Jarak RTH menunjukkan nilai koefisien korelasi $-0,543 * *$ yang artinya memiliki hubungan yang sangat kuat dimana dapat dijelaskan bahwa semakin kecil jarak RTH dari tempat tinggal semakin tinggi tingkat partisipasi masyarakat. Dan yang kedua adalah 
tingkat umur, dimana nilai koefisien korelasi -0,294* menunjukkan hubungan yang kuat dan berbanding terbalik. Semakin rendah tingkat usia seseorang, semakin tinggi tingkat partisipasinya.

Tabel 2. Tabel analisis SPSS korelasi

\begin{tabular}{|c|c|c|c|c|c|c|}
\hline & & DULU & $\begin{array}{c}\text { LAMA } \\
\text { TINGGAL }\end{array}$ & USIA & PENDIDIKAN & JARAK RTH \\
\hline \multirow[t]{3}{*}{ DULU } & $\begin{array}{l}\text { Correlation } \\
\text { Coefficient }\end{array}$ & 1.000 & -.010 & $-.294^{*}$ & -.066 & $-.543^{* *}$ \\
\hline & Sig. (2-tailed) & . & .941 & .023 & .616 & .000 \\
\hline & $\mathrm{N}$ & 60 & 60 & 60 & 60 & 60 \\
\hline \multirow[t]{3}{*}{ USIA } & $\begin{array}{l}\text { Correlation } \\
\text { Coefficient }\end{array}$ & $-.294^{*}$ & .098 & 1.000 & -.055 & $.306^{*}$ \\
\hline & Sig. (2-tailed) & .023 & .457 & . & .676 & .018 \\
\hline & $\mathrm{N}$ & 60 & 60 & 60 & 60 & 60 \\
\hline \multirow[t]{5}{*}{$\begin{array}{l}\text { JARAK } \\
\text { RTH }\end{array}$} & $\begin{array}{l}\text { Correlation } \\
\text { Coefficient }\end{array}$ & $-.543^{* *}$ & -.184 & $.306^{*}$ & .152 & 1.000 \\
\hline & Sig. (2-tailed) & .000 & .160 & .018 & .245 & . \\
\hline & $\mathrm{N}$ & 60 & 60 & 60 & 60 & 60 \\
\hline & $\begin{array}{l}* \text {. Correlation is significant at } \\
\text { the } 0.05 \text { level ( } 2 \text {-tailed). }\end{array}$ & & & & & \\
\hline & $\begin{array}{l}* * \text {. Correlation is significant at } \\
\text { (2-tailed). }\end{array}$ & 0.01 level & & & & \\
\hline
\end{tabular}

Strategi peningkatan partisipasi masyarakat dalam penanggulangan bencana dirumuskan berdasarkan harapan yang sesuai dengan teori tangga partisipasi masyarakat menurut Arnstein seperti terlihat pada Tabel 3 menjadi masukan dalam merumuskan strategi.

Tabel 3. Harapan masa depan tentang partisipasi masyarakat

\begin{tabular}{|c|c|c|c|c|}
\hline No & $\begin{array}{l}\text { Tangga/ } \\
\text { Tingkatan } \\
\text { Partisipasi }\end{array}$ & Penjabaran untuk Ruang Terbuka Publik & $\begin{array}{l}\text { Masyarakat } \\
\text { Tanggap } \\
\text { Bencana }\end{array}$ & $\begin{array}{l}\text { Harapan } \\
\text { Ke depan }\end{array}$ \\
\hline 8 & $\begin{array}{l}\text { Community } \\
\text { Control }\end{array}$ & $\begin{array}{l}\text { Pengembangan Ruang } \begin{array}{l}\text { Terbuka Publik } \\
\text { sepenuhnya dilakukan oleh masyarakat, } \\
\text { termasuk dalam penanggulangan bencana }\end{array}\end{array}$ & 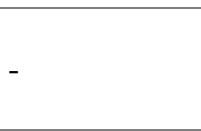 & 4 \\
\hline 7 & $\begin{array}{l}\text { Delegated } \\
\text { Power }\end{array}$ & $\begin{array}{l}\text { Pengembangan ruang terbuka yang didanai } \\
\text { oleh pemerintah, tetapi pelaksanaan dan } \\
\text { penentuannya sebagai titik kumpul bencana } \\
\text { diserahkan sepenuhnya kepada masyarakat }\end{array}$ & - & 9 \\
\hline 6 & Partnership & $\begin{array}{l}\text { Pengembangan ruang terbuka publik dilakukan } \\
\text { bersama oleh pemerintah dan masyarakat, baik } \\
\text { dalam penentuan, perencanaan, maupun } \\
\text { pelaksanaannya sebagai titik kumpul bencana }\end{array}$ & - & 13 \\
\hline 5 & Consultation & $\begin{array}{l}\text { Pemerintah mengajak masyarakat berembuk } \\
\text { atau kesepakatan dalam penentuan ruang } \\
\text { terbuka publik sebagai titik kumpul bencana di } \\
\text { lingkungan perumahan }\end{array}$ & - & 26 \\
\hline 4 & Placation & $\begin{array}{l}\text { Pemerintah memberi penyuluhan dan memberi } \\
\text { pelatihan kepada masyarakat untuk tanggap } \\
\text { bencana }\end{array}$ & 6 & 8 \\
\hline 3 & Informing & $\begin{array}{l}\text { Pemerintah mendengarkan saran masyarakat } \\
\text { tentang penentuan ruang terbuka publik } \\
\text { sebagai titik kumpul bencana tetapi tidak } \\
\text { semuanya dipakai }\end{array}$ & 7 & - \\
\hline
\end{tabular}




\begin{tabular}{lllll}
\hline 2 & Therapy & $\begin{array}{l}\text { Masyarakat hanya diberi brosur atau petunjuk 2 } \\
\text { terhadap ruang terbuka publik sebagai titik } \\
\text { kumpul bencana }\end{array}$ & - \\
\hline 1 & Manipulation & $\begin{array}{l}\text { Masyarakat hanya mendapatkan penjelasan 45 } \\
\text { tentang pentingnya ruang terbuka publik } \\
\text { sebagai titik kumpul bencana di lingkungannya }\end{array}$ & - \\
\hline
\end{tabular}

Berdasarkan Tabel 3 terlihat bahwa ekspektasi publik berada pada tangga keempat Arnstein, Consultation. Sebanyak 26 responden atau 43\% dari jumlah responden sangat mengharapkan pemerintah mengundang masyarakat untuk berdiskusi atau menyepakati penetapan ruang terbuka publik sebagai titik temu bencana di lingkungan permukiman.

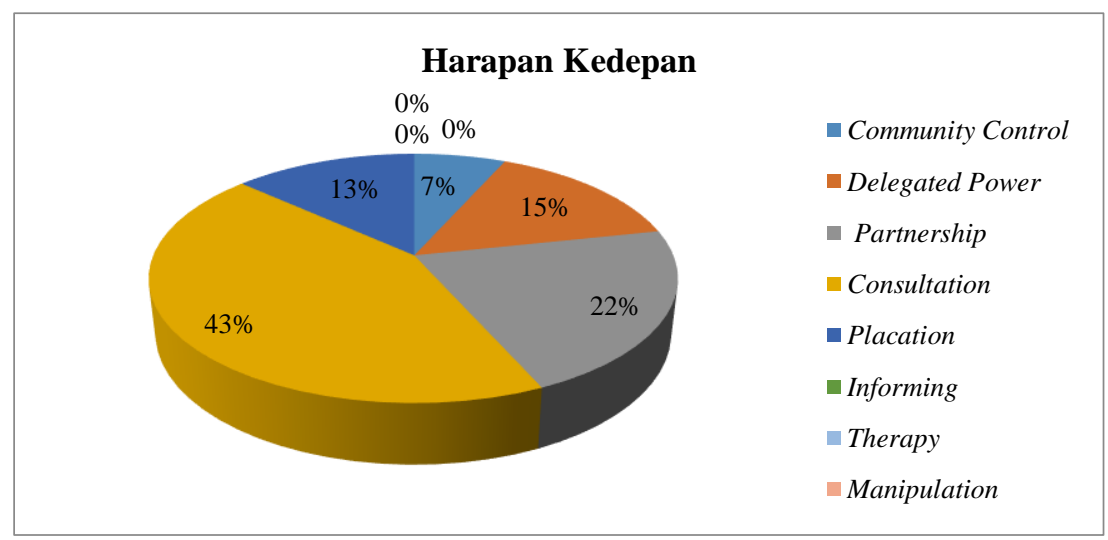

Gambar 5. Persentase harapan terhadap tingkat partisipasi masyarakat

Berdasarkan ekspektasi pada Tabel 3, maka dapat dirumuskan strategi antara lain: melakukan penyuluhan, kerjasama pemerintah, memberikan pelatihan tanggap bencana, bahkan memberikan kesempatan kepada masyarakat untuk berpartisipasi penuh dalam beberapa program pengembangan ruang terbuka publik seperti penetapan titik temu bencana yang telah disepakati melalui konsultasi, diskusi, dan lain-lain sesuai dengan harapan masyarakat pada umumnya.

\section{KESIMPULAN}

Tingkat partisipasi masyarakat dalam pengembangan ruang terbuka publik sebagai titik kumpul bencana di Kelurahan Maccini Sombala Kecamatan Tamalate Makassar berada pada tingkatan terendah dalam tangga partisipasi Sherry Arnstein yaitu manipulation ( $75 \%$ responden). Masyarakat hanya mendapatkan penjelasan tentang pentingnya pengembangan ruang terbuka publik sebagai titik kumpul bencana di lingkungannya.

Faktor-faktor yang berpengaruh terhadap tingkat partisipasi masyarakat dalam pengembangan ruang terbuka publik sebagai titik kumpul bencana di Kecamatan Tamalate Makassar khususnya pada Kelurahan Maccini Sombala, adalah usia dan jarak ruang terbuka publik dari rumah. Sedangkan strategi untuk meningkatkan partisipasi masyarakat dalam efektivitas ruang terbuka publik sebagai titik kumpul bencana di Kota Makassar khususnya di Kelurahan Maccini Sombala: mengadakan penyuluhan, kerjasama pemerintah, pemberian pelatihan tanggap bencana, bahkan memberi kesempatan masyarakat berpartisipasi penuh pada beberapa program pengembangan ruang terbuka publik seperti penentuan titik kumpul bencana yang telah disepakati 
melalui konsultasi, diskusi, dan lain sebagainya sesuai dengan harapan-harapan masyarakat pada umunya.

\section{DAFTAR PUSTAKA}

Abraham W, A., R. Rachmawati., \& E. T. W. Mei (2015). Penentuan jalur evakuasi dan titik kumpul partisipatif dalam upaya pengurangan resiko bencana Gunung Merapi. Jurnal Bumi Indonesia, 4(3).

At-Toyibi, M. N. H., \& S. D. Kusuma. (2020). Dasar pemikiran arsitektur humanistik: Pemahaman dan tokohnya dari era ke era. Sinetika, Jurnal Arsitektur, 17(1), 49-53.

Badan Kepegawaian dan Pengembangan Sumber Daya Daerah (BKPSMD) Kota Makassar (Diakses 15 Juli 2019)

Badan Nasional Penanggulangan Bencana. (2016). Panduan teknis fasilitator. (Edisi Desember). Jakarta: BNPB.

Elisa, Sari., \& D. Rina. (2018). Pendekatan hierarki Abraham Maslow pada prestasi kerja karyawan PT. Madubaru (Pg Madukismo) Yogyakarta. Jurnal Perilaku dan Strategi Bisnis, 6(1), 58-77.

Iskandar. (2016). Implementasi Teori Hirarki Kebutuhan Abraham Maslow Terhadap Peningkatan Kinerja Pustakawan. Jurnal Ilmu Perpustakaan, Informasi, dan Kearsipan Khizanah Al-Hikmah, 4(1).

Kementerian Pekerjaan Umum. (2011). Permen PU No. 20 tahun 2011: Pedoman Penyusunan RDTR dan Peraturan Zonasi Kabupaten/Kota. Jakarta: Kementerian Pekerjaan Umum.

Muazaroh Siti. (2019). Kebutuhan manusia dalam pemikiran Abraham Maslow (Tinjauan Maqasid Syariah). Jurnal Al-Mazahib, 7(1), 17-33.

Rahmadi, R. (2015). Partisipasi Masyarakat Ddalam Pengembangan Ruang Terbuka Hijau di Kecamatan Tamalate Kota Makassar. [Skripsi]. Makassar: Universitas Hasanuddin.

Undang-Undang Desa No. 6 tahun 2014 tentang Desa. 